\title{
Employer Branding Strategy: An Empirical Study on Private Banks in Bangladesh
}

\section{Tahmina Akter}

Senior Lecturer, Department of Business Administration, Bangladesh University, Dhaka, BANGLADESH

E-mail for correspondence: tahminabunny@gmail.com

https://doi.org/10.18034/abr.v9i3.274

\begin{abstract}
The Banking industry of Bangladesh is the most contributing sector in the growth of the country's economy. To grow and maintain this contribution, operating banks should be careful in talent hiring. Employer branding strategy (EB) helps in this regard by branding the employer's image particularly. This study aims to explore the current practice of EB strategy in private banks and the presence of its factors. This study showed that both employers and employees are not conscious of the term. Also, the presence of the factors in the organization is not satisfactory. This study provides suggestions in designing and implementing employer branding strategy consciously and in a planned way so that both employers and employees can reap the maximum benefits of EB strategy.
\end{abstract}

Key words: Branding, Employer, Employer branding, Employer brand loyalty

\section{INTRODUCTION}

Before understanding the EB concept, both employer and branding concepts must be apprehending perfectly. Employers are the persons who provide job opportunities, whose aim is to recruit bona fide employees, working for the organization goal. It is employers who decide what functional and economic benefits employees will get from the organization for their talent and performance. Contrariwise, employees are the individuals who seek their desired jobs where they can utilize their knowledge and skill and, get a total package of remuneration, recognition and facilities. Employees can achieve the target and bring the desired success for both the company and themselves. Branding is a pure marketing concept. It means differentiating the product offerings from others by providing extra value to customers. Brand has been defined by Kotler as "a name, term, sign, symbol, logo or a combination of them which is designed to locate goods and services of one seller or a group of seller and to distinguish them from those of competitors"(Kotler, 1991). Branding principles have been used by organizations for several years to differentiate their products, services and firms. Whatever, the practices of branding activities in differentiating the employer's image in the job market are termed as employer branding. This concept was first introduced in 1990. In 1996 Ambler and Barrow define EB as "the bundle of functional, economic and psychological benefits provided by employment, and identified with the employing company" (Ambler and Barrow, 1996). Employer brand denotes an organization's reputation as an employer (Barrow and Mosley, 2005). According to Minchington (2005), employer brand is the image of an organization as a 'great place to work.'

This strategy ensures the right match between employer and employee, meaning that employees share the same values as do company, reduces the employee turnover, and increases the overall company productivity and efficiency, which ultimately results in the customer's satisfaction. Worldwide, companies are applying EB strategy to attract and retain the talents to a great deal. Many firms have developed formal employer branding or are interested in developing such a program (Conference Board, 2001). In neighboring country India, the EB strategy has been used aggressively and proactively to differentiate talent management (Parmar, 2014). New Zealand creates employer brand proposition to hire skilled and qualified talents (Parmar, 2014). In Bangladesh, the term is relatively theoretically new to many companies though many of them applied it strategically. In this research, the private banking sector of Bangladesh has been selected as this is the most promising one in our economy. This study intended to investigate the latitude of familiarity with the EB concept and the presence of its factors in private banks in Bangladesh. 


\section{ObJectives Of the Study}

The prime purpose of this study is to know about the practices of employer branding in private banks in Bangladesh; for this purpose, the investigation attempts to look at the following issues:

- To define the concept of employer branding.

- To identify the familiarity of both the employers and employees with the concept of EB.

- To explore the presence of the success factors of EB strategy in the selected companies.

- To provide recommendations for the effective implementation of EB strategy in private banks in Bangladesh.

\section{Methodology OF THE Study}

The researcher has used a descriptive research design to conduct the study. The study is based on both primary data and secondary data. A structured questionnaire is designed to collect Primary data which is mostly designed around the factors of employer branding strategy. The factors were collected from the previous researches. The questionnaire was administered in personal interview with respective personnel of the organization. The secondary data was collected from various published documents like books, journals, newspapers and magazines and websites.

\section{Determining the SAmpling TeChNique AND SAMPLE SIZE}

The researcher selected 50 respondents from five selected private banks based on the non-probability convenience sampling method. Respondents have been divided into two groups for the analysis purpose: employers (who give jobs) and employees (who work or seek jobs). The employer's group includes ten respondents, head of HR, and senior HR manager from each of the five selected organizations. The employee group includes 40 employees taking eight employees from each of the five organizations. Employees were of various positions like the junior officer, senior officer, executive officer, senior executive officer, assistant officer, principal officer, senior principal officer, and AVP. These two groups of respondents helped the researcher to understand the opinion gap between the employers and the employees regarding the practices of $\mathrm{EB}$ in their organizations.

\section{Data Analysis TeChNique}

Collected data has been analyzed using descriptive statistics like crosstab. Likert scale method has been used in questionnaire design. Each scale item has five response categories ranging from 'strongly agree' to 'strongly disagree', and each statement has been assigned a numeric score ranging from 1 to 5 .

\section{LITERATURE REVIEW}

Branding and Employer Branding: The root of employer branding lies in the concept of branding. The idea of Branding was basically used to distinguish tangible products, but over the time, it has been applied to distinguish people, places and firms (Peters, 1999). According to recent marketing literature a brand has massive impact on the company as an employer and how external stakeholders define the organization, the corporate brand, and the firm as a future workplace (Davies, 2008; Foster et al., 2010; Gaddam, 2008). The application of branding principles to human resource management has been termed "Employer Branding."(Backhaus and Tikoo, 2004) It is a new strategy for companies to differentiate their employer's image to the current and potential employees as the best employer. Moroko and Uncles (2008) said that branding and employer branding are closely related. Features of the branding and employer branding are consistent. Backhaus and Tikoo (2004) contributed greatly by proposing a theoretical framework of EB and defined as "the process of building an identifiable and unparalleled employer identity." Sullivan (2004) identifies EB as "a targeted, long-term strategy to govern the awareness and feelings of employees, potential employees, and related stakeholders regarding an individual company". According to Martin et al. (2011), EB is "a generalized recognition for being known among key stakeholders for providing a high-quality employment experience, and a distinctive organizational identity which employees value, engage with and feel confident and happy to promote to others". In total, employer branding is a process of creating a unique, distinctive and clear image in the heart of employees so that employee's objectives properly match the company's goal and become the company's most valuable asset.

Employer Branding Framework: The EB framework was proposed by the Backhaus and Tikoo (2004) for further development in the understanding of employer branding. Branding the employers depends on the creation of three factors: employer brand association, organization identity, and organizational culture. Brand associations are the reflections and feelings that a brand name stimulates in the minds of consumers (Aaker, 1991). Brand associations can be verbalized but also might reside at a more sensory level- in other words; consumers have a feeling about a brand, an emotional response, or the memory of a smell, taste, or other sensation (Supphellen, 2000). Just like product brand association, employer brand association means creating a mental map in the mind of targeted customers (employees- internal and external) regarding the employers that in turn will create a clear and distinctive image of the workplace. These associations can be compensation, career growth, time flexibility, work flexibility, leadership style, etc. Employer image will attract potential employees to choose the organization to 
work. Brand loyalty means the affection that a consumer has to a brand (Aaker, 1991). A customer who is loyal to a brand is will not switch to other brands, especially when that brand goes through a change or is impaired by the competitive actions of other brands. At the core of brand loyalty is the positive exchange relationship that results from the long establishment of trust between the product and the consumer (Morgan and Hunt, 1994). Similarly employer brand loyalty means an employee's attachment with employers. Employer branding creates organization identity and organization culture that effectively create employer brand loyalty and increase the employee productivity. When brand loyal customers keep up purchasing a product, even though the product is going through difficulties, brand loyal employees stay besides the company, even when conditions might warrant them to consider other employers (Backhaus and Tikoo, 2004).

Figure 1: Employer Branding Framework

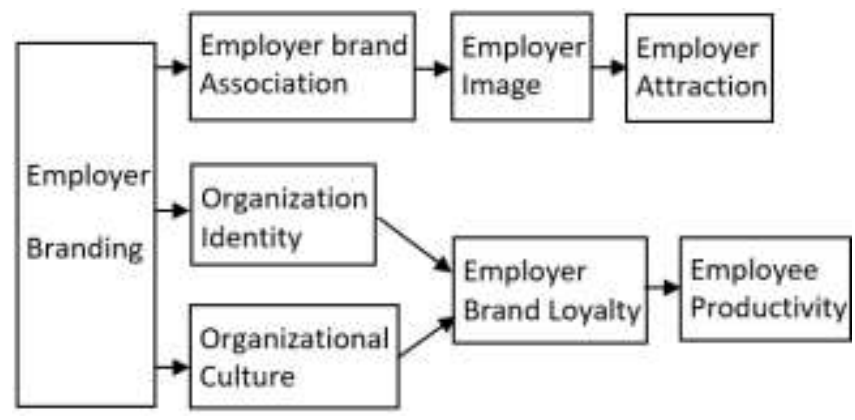

Source: Backhaus and Tikoo (2004)

Factors of Employer Branding: EB strategy consists of several factors. Organizations can practice EB successfully by installing these factors. According to Alpa Parmar, the factors that impact the EB are 1. Reputation/ integrity of employers, 2. Culture, 3.Recruitment/orientation, 4. Pay and benefits, 5 . Work /Life balance, 6 . Leadership and management, and 7. Performance management, growth and development. Of these seven factors, four have proven to be crucial for a large majority of high performing employees. These are 1. Culture 2. Pay and benefits 3. Leadership and management and 4 . Performance management, growth, and development. (Parmar, 2014). To be successful, employer branding must include each of these eight important factors: a) A culture of sharing and continuous improvement, b) A balance between good management and high productivity, c) Obtaining public recognition, d) Employees "proactively" telling stories, e) Getting talked about and f) Becoming a benchmark firm (Sullivan, 2004).

Benefits of Employer Branding: The Practice of EB entitles the organization to enjoy several significant advantages. In this era, using employer branding to differentiate the organization to attract the best talents is a crying need in fact. Every organization analyzes the costs and benefits of every decision and action before implementing it. A strong employer branding strategy combined with stronger attraction and high employee engagement will definitely results in improved profit and unique competitive advantage (Figurski and Matuska, 2013). Hewitt Associates reveal in their study that effort to strengthen employer brand will reap enhanced employee attraction, retention, and engagement (Mosley, 2009). Planned and effective EB strategies help the organization to achieve long-term benefits like strong competitive advantage, increased employee engagement, significantly enhanced talent pipeline, greater diversified workforce, stronger employer culture, stronger public relation strategies, improved organizational brand image, increased shareholder value (www.kellyservices.com.my).

\section{DATA ANALYSIS AND INTERPRETATION}

Familiarity with the Concept: The first statement respondents were presented is that they are familiar with the theoretical concept of EB. In response, table 1 below reveals that among ten employers, 4 (40\% within position category) are fully aware of the concept and 6 (60\% within the position category) are not fully aware. On the other hand, among 40 employees, 7 (17.5\% within the position category) said that they are fully aware, while $33(82.5 \%$ within position category) said they are not fully aware of the concept. In the table 1, percentage says that employers are more aware then employees.

Table 1: Familiarity with the Concept "Employer Branding"

\begin{tabular}{|c|c|c|c|c|c|}
\hline & \multicolumn{2}{|c|}{$\begin{array}{l}\text { Familiarity with } \\
\text { the concept } \\
\text { "Employer } \\
\text { Branding" }\end{array}$} & \multirow[t]{2}{*}{ Total } \\
\hline & & & $\begin{array}{l}\text { Fully } \\
\text { Agree }\end{array}$ & $\begin{array}{c}\text { Not Fully } \\
\text { Agree }\end{array}$ & \\
\hline \multirow{6}{*}{$\begin{array}{l}\text { Position } \\
\text { category }\end{array}$} & \multirow{3}{*}{ Employers } & Count & 4 & 6 & 10 \\
\hline & & $\begin{array}{l}\text { \% within } \\
\text { position } \\
\text { category }\end{array}$ & $40.0 \%$ & $60.0 \%$ & $100.0 \%$ \\
\hline & & $\%$ of Total & $8.0 \%$ & $12.0 \%$ & $20.0 \%$ \\
\hline & \multirow{3}{*}{ Employees } & Count & 7 & 33 & 40 \\
\hline & & $\begin{array}{l}\text { \% within } \\
\text { position } \\
\text { category }\end{array}$ & $17.5 \%$ & $82.5 \%$ & $100.0 \%$ \\
\hline & & $\%$ of Total & $14.0 \%$ & $66.0 \%$ & $80.0 \%$ \\
\hline \multirow{3}{*}{\multicolumn{2}{|c|}{ Total }} & Count & 11 & 39 & 50 \\
\hline & & $\begin{array}{l}\text { \% within } \\
\text { position } \\
\text { category }\end{array}$ & $22.0 \%$ & $78.0 \%$ & $100.0 \%$ \\
\hline & & $\%$ of Total & $22.0 \%$ & $78.0 \%$ & $100.0 \%$ \\
\hline
\end{tabular}

Most of the respondents agreed that attracting and retaining the right pool of talents is the main purpose of EB. $90 \%$ of the employers agreed and rested $10 \%$ were neutral. While $95 \%$ of the employees agreed, $2.5 \%$ disagreed, and $2.5 \%$ remained neutral. Therefore they almost have the same opinion about the purpose of employer branding. 
Table 2: Main Purpose is to Attract and Retain Right Pool of Talents

\begin{tabular}{|c|c|c|c|c|c|c|c|}
\hline & \multicolumn{4}{|c|}{$\begin{array}{l}\text { Main purpose is to attract } \\
\text { and retain right pool of } \\
\text { talents }\end{array}$} & \multirow[t]{2}{*}{ Total } \\
\hline & & & \begin{tabular}{|c|}
$\begin{array}{c}\text { trongly } \\
\text { agree }\end{array}$ \\
\end{tabular} & Agree & Neutral & \begin{tabular}{|c|} 
Dis \\
agree
\end{tabular} & \\
\hline \multirow{6}{*}{$\begin{array}{l}\text { Position } \\
\text { category }\end{array}$} & \multirow{3}{*}{$\begin{array}{c}\text { Emplo } \\
\text { yers }\end{array}$} & Count & 5 & 4 & 1 & 0 & 10 \\
\hline & & $\begin{array}{l}\text { \% within } \\
\text { position } \\
\text { category }\end{array}$ & $50.0 \%$ & $40.0 \%$ & $10.0 \%$ & $0.0 \%$ & $\begin{array}{c}100.0 \\
\%\end{array}$ \\
\hline & & $\begin{array}{l}\% \text { of } \\
\text { Total } \\
\end{array}$ & $10.0 \%$ & $8.0 \%$ & $2.0 \%$ & $0.0 \%$ & $20.0 \%$ \\
\hline & \multirow{3}{*}{$\begin{array}{c}\text { Emplo } \\
\text { yees }\end{array}$} & Count & 12 & 26 & 1 & 1 & 40 \\
\hline & & $\begin{array}{l}\text { \% within } \\
\text { position } \\
\text { category }\end{array}$ & $30.0 \%$ & $65.0 \%$ & $2.5 \%$ & $2.5 \%$ & $\begin{array}{c}100.0 \\
\%\end{array}$ \\
\hline & & $\begin{array}{l}\% \text { of } \\
\text { Total }\end{array}$ & $24.0 \%$ & $52.0 \%$ & $2.0 \%$ & $2.0 \%$ & $80.0 \%$ \\
\hline \multirow{3}{*}{\multicolumn{2}{|c|}{ Total }} & Count & 17 & 30 & 2 & 1 & 50 \\
\hline & & $\begin{array}{l}\text { \% within } \\
\text { position } \\
\text { category }\end{array}$ & $34.0 \%$ & $60.0 \%$ & $4.0 \%$ & $2.0 \%$ & $\begin{array}{c}100.0 \\
\%\end{array}$ \\
\hline & & $\begin{array}{l}\text { \% of } \\
\text { Total }\end{array}$ & $34.0 \%$ & $60.0 \%$ & $4.0 \%$ & $2.0 \%$ & $\begin{array}{c}100.0 \\
\%\end{array}$ \\
\hline
\end{tabular}

Respondents reacted differently to the statement that only the HR department is responsible for the implementation of EB in the organization. Only $10 \%$ of the employers agreed with the statement, $20 \%$ disagreed and $70 \%$ remained neutral. $47.5 \%$ of the selected employees' belief that the HR department is responsible. $20 \%$ disagreed, and $32.5 \%$ remained neutral. Therefore, it can be said that HR department alone is not responsible.

Table 3: HR Department is Responsible for Implementation

\begin{tabular}{|c|c|c|c|c|c|c|c|c|}
\hline & \multicolumn{5}{|c|}{$\begin{array}{l}\text { HR department is responsible for } \\
\text { implementation }\end{array}$} & \multirow[t]{2}{*}{\begin{tabular}{|l|l|} 
Total \\
\end{tabular}} \\
\hline & & & $\begin{array}{c}\text { Strongly } \\
\text { Agree }\end{array}$ & Agree & Netutral & \begin{tabular}{|c|} 
Dis \\
agree
\end{tabular} & \begin{tabular}{|l|} 
Strongly \\
Disagree
\end{tabular} & \\
\hline \multirow{6}{*}{$\begin{array}{l}\text { Position } \\
\text { category }\end{array}$} & \multirow{3}{*}{$\begin{array}{l}\text { Empl } \\
\text { oyers }\end{array}$} & Count & 0 & 1 & 7 & 2 & 0 & 10 \\
\hline & & $\begin{array}{l}\text { \% within } \\
\text { position } \\
\text { catezory }\end{array}$ & $0.0 \%$ & $10.0 \%$ & $700 \%$ & $200 \%$ & $0.0 \%$ & $1000 \%$ \\
\hline & & $\begin{array}{l}\text { \%o of } \\
\text { Total }\end{array}$ & $0.0 \% 6$ & $2.0 \% 16$ & $140 \%$ & $4.0 \%$ & $0.0 \%$ & $20.0 \%$ \\
\hline & \multirow{3}{*}{$\begin{array}{l}\text { Empl } \\
\text { oyees }\end{array}$} & Count & 7 & 12 & 13 & 7 & 1 & 40 \\
\hline & & $\begin{array}{l}\% \text { within } \\
\text { position } \\
\text { category }\end{array}$ & $17.3 \%$ & $30.0 \%$ & $32.5 \%$ & $17,5 \%$ & $25 \%$ & $1000 \%$ \\
\hline & & $\begin{array}{l}\% \text { of } \\
\text { Total }\end{array}$ & $14.0^{\circ}$ & $24.0 \%$ & $26.0 \%$ & $1400_{t}$ & $20 \%$ & $50.0 \%$ \\
\hline \multirow{3}{*}{ Total } & & Count & 7 & 13 & 20 & 9 & 1 & 50 \\
\hline & & $\begin{array}{l}96 \text { within } \\
\text { position } \\
\text { category }\end{array}$ & $14.0 \%$ & $20.0 \%$ & $40.0 \%_{0}^{\circ}$ & $180 \%$ & $2.0 \%$ & $100.0 \%$ \\
\hline & & $\begin{array}{l}\% \text { of } \\
\text { Total }\end{array}$ & $14.0 \%$ & $200 \%$ & $400 \%$ & $180 \%$ & $20 \%$ & $1000 \%$ \\
\hline
\end{tabular}

Respondents were also asked to comment on whether their organization is a good place to work. $90 \%$ of the employers' belief that their organization is a good place to work and $10 \%$ remained neutral. $72.5 \%$ of the employees agreed with the statement when $15 \%$ belief that their organization is not a good place to work. Rests remained neutral.

Table: 4 Good Place to Work

\begin{tabular}{|c|c|c|c|c|c|c|c|c|}
\hline & \multicolumn{5}{|c|}{ Good place to work } & \multirow{2}{*}{ Total } \\
\hline & & & $\begin{array}{l}\text { Strongly } \\
\text { Agree }\end{array}$ & Agree & Neutral & Disagree & $\begin{array}{l}\text { Strongly } \\
\text { Disagree }\end{array}$ & \\
\hline \multirow{6}{*}{$\begin{array}{l}\text { Position } \\
\text { category }\end{array}$} & \multirow{3}{*}{$\begin{array}{l}\text { Empl } \\
\text { oyers }\end{array}$} & Count & 2 & 7 & 1 & 0 & 0 & 10 \\
\hline & & $\begin{array}{l}\text { \% within } \\
\text { position } \\
\text { category }\end{array}$ & $20.0 \%$ & $70.0 \%$ & $10.0 \%$ & $0.0 \%$ & $0.0 \%$ & $\begin{array}{c}100,0 \\
\%\end{array}$ \\
\hline & & $\begin{array}{l}\% \text { of } \\
\text { Total }\end{array}$ & $4.0 \%$ & $14.0 \%$ & $2.0 \%$ & $0.0 \%$ & $0.0 \%$ & $20,0 \%$ \\
\hline & \multirow{3}{*}{$\begin{array}{l}\text { Empl } \\
\text { oyees }\end{array}$} & Count & 4 & 25 & 5 & 3 & 3 & 40 \\
\hline & & $\begin{array}{l}\text { 9. within } \\
\text { position } \\
\text { category }\end{array}$ & $10.0 \%$ & $62.5 \%$ & $12.5 \%$ & $7.5 \%$ & $75 \%$ & $\begin{array}{c}100.0 \\
\%\end{array}$ \\
\hline & & $\begin{array}{l}\% \text { of } \\
\text { Total }\end{array}$ & $8.0 \%$ & $50.0 \%$ & $10.0 \%$ & $6.0 \%$ & $6.0 \%$ & $80.0 \%$ \\
\hline \multirow{3}{*}{\multicolumn{2}{|c|}{ Total }} & Count & 6 & 32 & 6 & 3 & 3 & 50 \\
\hline & & $\begin{array}{l}\text { \%o within } \\
\text { position } \\
\text { category }\end{array}$ & $12.0 \%$ & $64.0 \%$ & $12.0 \%$ & $6.0 \%$ & $6.0 \%$ & $\begin{array}{c}100.0 \\
\%\end{array}$ \\
\hline & & $\begin{array}{l}\% \text { of } \\
\text { Total }\end{array}$ & $12.0 \%$ & $64.0 \%$ & $12.0 \%$ & $6.0 \%$ & $6.0 \%$ & $\begin{array}{c}100.0 \\
\%\end{array}$ \\
\hline
\end{tabular}

\section{Presence of the Success factors of EMPLOYER BRANDING}

In response to the statement that the organization provides high compensation packages, nine employers (90\% within the position category) agreed, and only 1 (10\% within the position category) disagreed with the statement. Among the employees, 1(2.5\%within the position category) strongly agreed, $15(37.5 \%$ within the position category) Agreed, 5 (12.5\% within the position category) remained neutral, and 14 (35\% within the position category) disagreed with the statement. It is revealed that employers think they are giving high compensation to employees, whereas employees think themselves deprived of having high compensation.

Table 5: Provides High Compensation Package

\begin{tabular}{|c|c|c|c|c|c|c|c|c|}
\hline & \multicolumn{5}{|c|}{ Frovides high compensation package } & \multirow[t]{2}{*}{ Total } \\
\hline & & & $\begin{array}{c}\text { Strongly } \\
\text { Agree }\end{array}$ & Agree & Neutral & Disagree & \begin{tabular}{|l|} 
Strongly \\
Disagree
\end{tabular} & \\
\hline \multirow{6}{*}{$\begin{array}{l}\text { Position } \\
\text { category }\end{array}$} & \multirow{3}{*}{$\begin{array}{l}\text { Emplo } \\
\text { yers }\end{array}$} & Count & 0 & 9 & D & 1 & 0 & 10 \\
\hline & & $\begin{array}{l}\% \text { within } \\
\text { position } \\
\text { cuterory }\end{array}$ & $0.0 \%$ & $90.0 \%$ & $0.9 \%$ & $10.0 \%$ & 0.00 & $100.0 \%$ \\
\hline & & Sof Total & $0.0 \%$ & 18.05 & $0.0 \%$ & 2.006 & $0.0 \%$ & $20.0 \%$ \\
\hline & \multirow{3}{*}{$\begin{array}{c}\text { Emplo } \\
\text { yeess }\end{array}$} & Count & 1 & 15 & 5 & I4 & 5 & 40 \\
\hline & & $\begin{array}{l}\text { 5. within } \\
\text { position } \\
\text { category }\end{array}$ & $2.5 \%$ & 3755 & 12.58 & $35.0 \%$ & $12.5 \%$ & $100,0 \%$ \\
\hline & & $\%$ of Total & $2.0 \%$ & $30.0 \%$ & $10.0 \%$ & $28.0 \%$ & $10.0 \%$ & $80.0 \%$ \\
\hline \multirow{3}{*}{\multicolumn{2}{|c|}{ Total }} & Count & 1 & 24 & 5 & 15 & 5 & 50 \\
\hline & & $\begin{array}{l}\% \text { within } \\
\text { position } \\
\text { category }\end{array}$ & $2.0 \%$ & $48.0 \%$ & $10.0 \%$ & $30.0 \%$ & $10.0 \%$ & $100.0 \% \mathrm{~s}$ \\
\hline & & Sof Total & $2.0 \%$ & $45,0 \%$ & $10.0 \%$ & $30.0 \%$ & $10.0 \%$ & $100.0 \%$ \\
\hline
\end{tabular}

From table 6, it is clear that seven among the ten employers ( $70 \%$ within the position category) agreed that their organizations have a well-developed culture that attracts employees to stay. When, although $57.5 \%$ of the selected employees agreed with the statement, 30\% 
disagreed. So, it reveals a gap between what employers think they are having and what employees expect from the organization.

Table 6: Organization has a Well Developed Culture that Attract Employees

\begin{tabular}{|c|c|c|c|c|c|c|c|}
\hline & \multicolumn{4}{|c|}{$\begin{array}{l}\text { Organization has a well developed } \\
\text { culture that attract employees }\end{array}$} & \multirow[t]{2}{*}{ Total } \\
\hline & & & \begin{tabular}{|c|} 
Strongly \\
Agree
\end{tabular} & Agree & Neutral & Disagree & \\
\hline \multirow{6}{*}{$\begin{array}{l}\text { position } \\
\text { category }\end{array}$} & \multirow{3}{*}{$\begin{array}{c}\text { Employ } \\
\text { ers }\end{array}$} & Count & 1 & 6 & 1 & 2 & 10 \\
\hline & & $\begin{array}{l}\% \text { within } \\
\text { position } \\
\text { category }\end{array}$ & $10.0 \%$ & $60.0 \%$ & $10.0 \%$ & $20.0 \%$ & $\begin{array}{c}100.0 \\
\%\end{array}$ \\
\hline & & $\%$ of Total & $2.0 \%$ & $12.0 \%$ & $2.0 \%$ & $4.0 \%$ & $\begin{array}{c}20.0 \\
\%\end{array}$ \\
\hline & \multirow{3}{*}{$\begin{array}{l}\text { Empl } \\
\text { oyees }\end{array}$} & Count & 2 & 21 & 5 & 12 & 40 \\
\hline & & $\begin{array}{l}\% \text { within } \\
\text { position } \\
\text { category }\end{array}$ & $5.0 \%$ & $52.5 \%$ & $12.5 \%$ & $30.0 \%$ & $\begin{array}{c}100.0 \\
\%\end{array}$ \\
\hline & & $\%$ of Total & $4.0 \%$ & $42.0 \%$ & $10.0 \%$ & $24.0 \%$ & $\begin{array}{c}80.0 \\
\%\end{array}$ \\
\hline \multirow{3}{*}{\multicolumn{2}{|c|}{ Total }} & Count & 3 & 27 & 6 & 14 & 50 \\
\hline & & $\begin{array}{l}\% \text { within } \\
\text { position } \\
\text { category }\end{array}$ & $6.0 \%$ & $54.0 \%$ & $12.0 \%$ & $28.0 \%$ & $\begin{array}{c}100.0 \\
\%\end{array}$ \\
\hline & & $\%$ of Total & $6.0 \%$ & $54.0 \%$ & $12.0 \%$ & $28.0 \%$ & $\begin{array}{c}100.0 \\
\%\end{array}$ \\
\hline
\end{tabular}

Respondents were asked to comment on whether the top management maintains a leadership strategy that influences employees to stay with the organization. $80 \%$ of the selected employers agreed with the statement \& $20 \%$ disagreed. $67.5 \%$ of the selected employees agreed, $10 \%$ remained neutral, and $15 \%$ disagreed.

Table 7: Top Management Maintains a Leadership Strategy that Influences Employees to Stay

\begin{tabular}{|c|c|c|c|c|c|c|c|c|}
\hline & \multicolumn{5}{|c|}{$\begin{array}{l}\text { Top management maintains a } \\
\text { leadership strategy that influences } \\
\text { employees to stay }\end{array}$} & \multirow[t]{2}{*}{ Total } \\
\hline & & & $\begin{array}{c}\text { Strongly } \\
\text { Agree }\end{array}$ & Agree & Neutral & $\begin{array}{c}\text { Dis } \\
\text { agree }\end{array}$ & \begin{tabular}{|l|} 
Strongly \\
Disagree
\end{tabular} & \\
\hline \multirow{6}{*}{$\begin{array}{l}\text { Position } \\
\text { category }\end{array}$} & \multirow{3}{*}{$\begin{array}{c}\text { Employ } \\
\text { ers }\end{array}$} & Count & 3 & 5 & 2 & 0 & 0 & 10 \\
\hline & & $\begin{array}{l}\text { So within } \\
\text { position } \\
\text { category }\end{array}$ & $30.0 \%$ & $\frac{50.0}{*}$ & $20.0 \%$ & $\begin{array}{l}0.0 \\
\%\end{array}$ & $0.0 \%$ & $\underset{\%}{100.0}$ \\
\hline & & $\%$ of Total & $6.0 \%$ & $\begin{array}{c}10.0 \\
\%\end{array}$ & $4.0 \%$ & $\begin{array}{l}0.0 \\
\%\end{array}$ & $0.0 \%$ & $\begin{array}{c}20.0 \\
\%\end{array}$ \\
\hline & \multirow{3}{*}{$\begin{array}{l}\text { Enipl } \\
\text { oyees }\end{array}$} & Count & 8 & 19 & 4 & 6 & 3 & 40 \\
\hline & & $\begin{array}{l}\text { \% within } \\
\text { position } \\
\text { category }\end{array}$ & $20.0 \%$ & $\stackrel{47.5}{\%}$ & $10.0 \%$ & $\begin{array}{c}15.0 \\
\%\end{array}$ & $7.5 \%$ & $\stackrel{100.0}{\%}$ \\
\hline & & $\%$ of Total & $16.0 \%$ & $\begin{array}{c}38.0 \\
\%\end{array}$ & $8.0 \%$ & $\begin{array}{c}12.0 \\
\%\end{array}$ & $6.0 \%$ & $\begin{array}{c}80.0 \\
\%\end{array}$ \\
\hline \multirow{3}{*}{\multicolumn{2}{|c|}{ Total }} & Count & 11 & 24 & 6 & 6 & 3 & 50 \\
\hline & & $\begin{array}{l}\text { \%o within } \\
\text { position } \\
\text { category }\end{array}$ & $22.0 \%$ & $\begin{array}{l}48.0 \\
\%\end{array}$ & $12.0 \%$ & $\underset{\%}{12.0}$ & $6.0 \%$ & $\begin{array}{c}100.0 \\
\%\end{array}$ \\
\hline & & $\%$ of Total & $22.0 \%$ & $\begin{array}{c}48.0 \\
\%\end{array}$ & $12.0 \%$ & $\begin{array}{c}12.0 \\
1 \%\end{array}$ & $6.0 \%$ & $\begin{array}{c}100.0 \\
\%\end{array}$ \\
\hline
\end{tabular}

Table 8 shows that $100 \%$ of selected employers agreed that their organization has enough career growth opportunity. But employee's response varied in this regard. $45 \%$ disagreed with the statement, and $47.5 \%$ agreed. The rest, $7.5 \%$ remained neutral. That means almost half of the employees don't think the available growth opportunity is enough for them.

Table 8: Organization Provides Enough Career Growth

\begin{tabular}{|c|c|c|c|c|c|c|c|}
\hline & \multicolumn{4}{|c|}{$\begin{array}{l}\text { Organization Provides } \\
\text { enough career growth }\end{array}$} & \multirow[t]{2}{*}{ Total } \\
\hline & & & $\begin{array}{c}\text { Strongly } \\
\text { Agree }\end{array}$ & Agree & Neutral & \begin{tabular}{|c|} 
Dis \\
agree
\end{tabular} & \\
\hline \multirow{6}{*}{$\begin{array}{l}\text { Position } \\
\text { category }\end{array}$} & \multirow{3}{*}{$\begin{array}{l}\text { Employ } \\
\text { ers }\end{array}$} & Count & 0 & 10 & 0 & 0 & 10 \\
\hline & & $\begin{array}{l}\text { \% within } \\
\text { position } \\
\text { category }\end{array}$ & $0.0 \%$ & $\begin{array}{c}100.0 \\
\%\end{array}$ & $0.0 \%$ & $\begin{array}{l}0,0 \\
\%\end{array}$ & $\begin{array}{c}100.0 \\
\%\end{array}$ \\
\hline & & $\%$ of Total & $0.0 \%$ & $20.0 \%$ & $0.0 \%$ & $\begin{array}{l}0.0 \\
\%\end{array}$ & $\begin{array}{c}20.0 \\
\%\end{array}$ \\
\hline & \multirow{3}{*}{$\begin{array}{l}\text { Empl } \\
\text { oyees }\end{array}$} & Count & 2 & 17 & 3 & 18 & 40 \\
\hline & & $\begin{array}{l}\% \text { within } \\
\text { position } \\
\text { category }\end{array}$ & $5.0 \%$ & $42.5 \%$ & $7.5 \%$ & $\begin{array}{c}45.0 \\
\%\end{array}$ & $\begin{array}{c}100.0 \\
\%\end{array}$ \\
\hline & & $\%$ of Total & $4.0 \%$ & $34.0 \%$ & $6.0 \%$ & $\begin{array}{c}36.0 \\
\%\end{array}$ & $\begin{array}{c}80.0 \\
\%\end{array}$ \\
\hline \multirow{3}{*}{\multicolumn{2}{|c|}{ Total }} & Count & 2 & 27 & 3 & 18 & 50 \\
\hline & & $\begin{array}{l}\% \text { within } \\
\text { position } \\
\text { category }\end{array}$ & $4.0 \%$ & $54.0 \%$ & $6.0 \%$ & $\begin{array}{c}36.0 \\
\%\end{array}$ & $\begin{array}{c}100.0 \\
\%\end{array}$ \\
\hline & & of Total & $4.0 \%$ & $54.0 \%$ & $6.0 \%$ & \begin{tabular}{c|}
36.0 \\
$\%$
\end{tabular} & $\begin{array}{c}100.0 \\
\%\end{array}$ \\
\hline
\end{tabular}

Regarding the statement of professional work-personal life balance, $50 \%$ of the selected employers agreed that the organization helps to maintain work-life balance, and 50\% disagreed. Among the employees, 30\% agreed, but 70\% disagreed, table 9 shows. It means employees face difficulty in maintaining the balance because of much work stress.

Table 9: Professional Work-Personal Life Balance

\begin{tabular}{|c|c|c|c|c|c|c|c|}
\hline & \multicolumn{4}{|c|}{$\begin{array}{l}\text { Professional work-Personal } \\
\text { Life balance }\end{array}$} & \multirow[t]{2}{*}{ Total } \\
\hline & & & $\begin{array}{c}\text { Strongly } \\
\text { Agree }\end{array}$ & Agree & \begin{tabular}{|c|} 
Dis \\
agree
\end{tabular} & \begin{tabular}{|l|} 
Strongly \\
Disagree
\end{tabular} & \\
\hline \multirow{6}{*}{$\begin{array}{l}\text { Position } \\
\text { category }\end{array}$} & \multirow{3}{*}{$\begin{array}{c}\text { Emplo } \\
\text { yers }\end{array}$} & Count & 0 & 5 & 4 & 1 & 10 \\
\hline & & \begin{tabular}{|l|}
$\%$ within \\
position \\
category
\end{tabular} & $0.0 \%$ & $50.0 \%$ & $40,0 \%$ & $10.0 \%$ & $\begin{array}{c}100.0 \\
\%\end{array}$ \\
\hline & & $\%$ of Total & $0.0 \%$ & $10.0 \%$ & $8.0 \%$ & $2.0 \%$ & $20.0 \%$ \\
\hline & \multirow{3}{*}{$\begin{array}{c}\text { Emplo } \\
\text { yees }\end{array}$} & Count & 1 & 11 & 17 & 11 & 40 \\
\hline & & $\begin{array}{l}\% \text { within } \\
\text { position } \\
\text { category } \\
\end{array}$ & $2.5 \%$ & $27.5 \%$ & $42.5 \%$ & $27.5 \%$ & $\begin{array}{c}100.0 \\
\%\end{array}$ \\
\hline & & $\%$ of Total & $2.0 \%$ & $220 \%$ & $34.0 \%$ & $22.0 \%$ & $80.0 \%$ \\
\hline \multirow{3}{*}{\multicolumn{2}{|c|}{ Total }} & Count & 1 & 16 & 21 & 12 & 50 \\
\hline & & $\begin{array}{l}\% \text { within } \\
\text { position } \\
\text { category }\end{array}$ & $2.0 \%$ & $32.0 \%$ & $42.0 \%$ & $24.0 \%$ & $\begin{array}{c}100.0 \\
\%\end{array}$ \\
\hline & & $\%$ of Total & $2.0 \%$ & $32.0 \%$ & $42.0 \%$ & $24.0 \%$ & $\begin{array}{c}100.0 \\
\%\end{array}$ \\
\hline
\end{tabular}

And in case of social value table 10 showing $70 \%$ of the employers' belief that the organization has a social value that creates a positive brand image, $20 \%$ disbelief, and rest were neutral. $67.5 \%$ of the employees interviewed agreed with the statement, while $22.5 \%$ disagreed. Rest, $10 \%$ remained neutral. 
Table 10: Company has a Social Value that Create Positive Employer Brand Image

\begin{tabular}{|c|c|c|c|c|c|c|c|c|}
\hline & \multicolumn{5}{|c|}{$\begin{array}{l}\text { Company has a social value that create } \\
\text { positive employer brand image }\end{array}$} & \multirow[t]{2}{*}{ Total } \\
\hline & & & $\begin{array}{l}\text { Strongly } \\
\text { Agree }\end{array}$ & Agree & Neutral & $\begin{array}{c}\text { Dis } \\
\text { agree }\end{array}$ & $\begin{array}{l}\text { Strongly } \\
\text { Disagree }\end{array}$ & \\
\hline \multirow{6}{*}{$\begin{array}{l}\text { Position } \\
\text { category }\end{array}$} & \multirow{3}{*}{$\begin{array}{c}\text { Employ } \\
\text { ers }\end{array}$} & Count & 2 & 5 & 1 & 2 & 0 & 10 \\
\hline & & $\begin{array}{l}\text { \% within } \\
\text { position } \\
\text { category }\end{array}$ & $20,0 \%$ & $50.0 \%$ & $10.0 \%$ & $20.0 \%$ & $0.0 \%$ & $100.0 \%$ \\
\hline & & $\%$ of Total & $4.0 \%$ & $10.0 \%$ & $2.0 \%$ & $4.0 \%$ & $0.0 \%$ & $20.0 \%$ \\
\hline & \multirow{3}{*}{$\begin{array}{c}\text { Employ } \\
\text { ees }\end{array}$} & Count & 3 & 24 & 4 & 8 & 1 & 40 \\
\hline & & $\begin{array}{l}\text { \% within } \\
\text { position } \\
\text { category }\end{array}$ & $75 \%$ & $60.0 \%$ & $10.0 \%$ & $20.0 \%$ & $25 \%$ & $100.0 \%$ \\
\hline & & $\%$ of Total & $6.0 \%$ & $48.0 \%$ & $8.0 \%$ & $16.0 \%$ & $2.0 \%$ & $80.0 \%$ \\
\hline \multirow{3}{*}{\multicolumn{2}{|c|}{ Total }} & Count & 5 & 29 & 5 & 10 & 1 & 50 \\
\hline & & $\begin{array}{l}\text { \% within } \\
\text { pocition } \\
\text { category }\end{array}$ & $10.0 \%$ & $58.0 \%$ & $10.0 \%$ & $20.0 \%$ & $2.0 \%$ & $100.0 \%$ \\
\hline & & Pu of Total & $10.0 \%$ & $58.0 \%$ & $10.0 \%$ & $20.0 \%$ & $20 \%$ & $100.0 \%$ \\
\hline
\end{tabular}

\section{MAJOR FINDINGS}

- People are less familiar with the concept of "Employer Branding" theoretically. The success factors of EB are also not familiar to them particularly. Besides, employees are less familiar with the concept than employers. They are just unaware of the term.

- Although people are not known to the term, they are trying to improve the organization's image by instilling the factors of EB. People are not practicing employer branding strategy intentionally and systematically; in fact they are implementing its factors unintentionally and randomly.

- HR department alone is not responsible for the implementation of the EB strategy.

- The immense difference between the opinion of the employers and the employees has been found regarding the presence of the EB factors in the workplace like compensation package, career growth, culture, work-life balance, management's leadership style, etc.

- There is no proper communication between what the company is giving and what employees are expecting.

- Most of the employers interviewed perceive that high compensation, career growth, well-developed culture, attractive leadership style, work-life balance, etc. are present in their organization, while employees perceive that these factors are present at a minimum level.

\section{RECOMMENDATIONS}

- Employers must learn about the concept so that they can implement it in the right way, at the right time, and in a systematic way.

- It is equally important for the employees to learn about the concept so that they can evaluate their organization in terms of the employer branding factors.
- Both the marketing department and the HR department must plan, execute, and implement an employer branding strategy with the assistance of other departments.

- The difference between the opinion of the employers and the employees should be removed by developing a crystalline communication system. Employers should understand employee's expectations regarding compensation, growth, work-life balance, etc. Employers must realize whether they are the company's expected talents.

- Organizations should exercise the EB strategy at the beginning of the recruitment process. It will help them to create a clear image of what their expected set of skills are and what they are going to pay for it in terms of compensation, growth, culture, management's leadership strategy, work-life balance, etc. Organization will be able to attract the right pool of talents in the right way at the right time. Employees will be satisfied, and job switching will eventually be reduced.

\section{Conclusions}

Employer branding is relatively a new strategy to create a competitive and distinctive employer image in the job market to attract the best talents. It is found from this research that EB is not widely and consciously being used by the organizations in Bangladesh, especially by private banks. Moreover, the concept is not well known to both employers and employees. The factors of EB are not dominating in the workplace. The study findings will verily contribute to design and implement an employer branding strategy effectively to differentiate themselves as best employers from others. However, because of the limited access, this research was conducted on a small sample. There is an ample scope to research in this area to explore the actual situation. Advance studies should be conveyed in this area on a large sample to avoid sampling error.

\section{REFERENCES}

Aaker, D. A. (1991). “Managing Brand Equity: Capitalizing on the Value of a Brand Name," The Free Press, New York, NY.

Ambler, T., and Barrow, S. (1996). "The Employer Brand," Journal of Brand Management, Vol. 4, No. 3, pp.185-206.

Backhaus, K., and Tikoo, S. (2004). "Conceptualizing and Researching Employer Branding," Career Development International, Vol. 9, No. 4/5, pp.501-517

Barrow, S. and Mosley, R. (2005) The Employer Brand: Bringing the Best of Brand Management to People at Work, UL: John Wiley \& Sons Ltd, 214 pp., (ISBN: 0470012730)

Chowdhury, A. H., Chowdhury, M. S. A., \& Imran, M. (2013). Branding strategies for service firms- a study on the selected Internet Service Providers (ISPs) in Bangladesh. Asian Business Review, 2(1), 47-53. https://doi.org/10.18034/abr.v2i1.122 
Davies, G. (2008). "Employer Branding and Its Influence on Managers", European Journal of Marketing, Vol. 42, No. 5, p.667-681

Figurski, I., and Matuska, E. (2013). "Employer Branding as a Human Resources Management Strategy," The Human Resources Management and Ergonomics, Vol. 3, p.35-51

Foster, C., Punjaisri, K., and Cheng, R. (2010). "Exploring the Relationship Between Corporate, Internal and Employer Branding," Journal of Product \& Brand Management, Vol. 19, No. 6, pp. $401-409$

Gaddam, S. (2008). "Modeling Employer Branding Communication: The Softer Aspect of HR Marketing Management," The Icfai Journal of Soft Skills, Vol. 2, No. 1, pp.45-55

Kelly Services (2013). Building a Strong Employer Brand at all Times for Sustainable Organization. (Online) Available on: www.kellyservices.com.my.

Kotler, P. (1991) Marketing Management. 7th Edition, PrenticeHall, Englewood Cliffs.

Martin, G., Gollan, P. \& Grigg, K. (2011). “Is There a Bigger and Better Future for Employer Branding? Facing Up to Innovation, Corporate Reputations and Wicked Problems in SHRM," The International Journal of Human Resource Management, Vol. 22, No. 17, pp.3618-3637

Minchington, B. (2005) Employer Brand Leadership - A Global Perspective. Torrensville: Collective Learning Australia, 319 P. ISBN 978-0-646-53648-4
Morgan, R.M., and Hunt, S.D. (1994), "The Commitment-Trust Theory of Relationship Marketing," Journal of Marketing, Vol. 58, pp.20-38.

Moroko, L. \& Uncles, M. (2008). "Successful Employer Brands," Brand Management, Vol. 16, No. 3, PP.160-175

Mosley, R. (2009). “Employer Brand: The Performance Driver No Business Can Ignore," Shoulders of Giants Publication.

Parmar, A. (2014). "The Role of Hr Department in Employer Branding at Public and Private Sector," Journal of Human Resources Management and Labor Studies. Vol. 2, No. 2, pp.201225

Peters, T. (1999). "The Brand You 50: Fifty Ways to Transform Yourself from an Employee into a Brand that Shouts Distinction," Knopf Publishers, New York, NY.

Sullivan, J. (2004). The 8 Elements of a Successful Employment Brand. ER Daily. Retrieved on 14 January 2015 from http:/ / www.ere.net/2004/02/23/the-8-elements-of-asuccessful-employment-brand.

Supphellen, M. (2000). "Understanding Core Brand Equity: Guidelines for In-Depth Elicitation of Brand Associations," International Journal of Market Research, Vol. 42, pp.319-38.

The Conference Board, (2001). “Engaging Employees through Your Brand," New York.

$--0-$ 
Online Archive: https://abc.us.org/ojs/index.php/abr/issue/archive 